\title{
PKM PELATIHAN MANAJEMEN REFERENSI PUBLIKASI PADA KELOMPOK MUSYAWARAH GURU MATA PELAJARAN (MGMP) MATEMATIKA TINGKAT SMP
}

\author{
Andi Yunarni Yusri¹ Akbar Taufik² Ahmad Yusuf3 \\ STKIP Andi Matappa' ${ }^{1}$ yunarniyusri@gmail.com \\ Universitas Pancasakti Makassar², akbar.taufik@unpacti.ac.id \\ STKIP Andi Matappa3, ahmadyusuf@gmail.com
}

\begin{abstract}
Abstrak
Referensi merupakan aspek yang sangat penting dalam dunia akademis. Seorang akademisi tentunya tidak dapat dipisahkan dari buku, jurnal, ataupun artikel dan makalah. Tidak terlalu mengherankan bila seorang akademisi memiliki referensi dengan jumlah hampir satu ruangan kerja bahkan lebih. Seiring dengan perkembangan teknologi, hampir semua referensi ilmiah tersebut telah dialih bentuk menjadi format digital dalam bentuk dokumen/file komputer. Hal ini tentunya sangat membantu sekali sehingga penyimpanan referensi tidak lagi memerlukan ruangan fisik yang besar atau banyak, namun cukup disimpan dalam harddisk seukuran telapak tangan. Tujuan PKM ini adalah: 1) Meningkatkan keterampilan guru dalam membuat referensi publikasi melalui software; 2) Untuk mendukung pelaksanaannya, Metode yang ditawarkan adalah pemberian materi pelatihan tentang manajemen referensi publikasi.
\end{abstract}

Kata Kunci: PKM, Manajemen Referensi Publikasi, MGMP

\section{Abstract}

Reference is a very important aspect in academia. An academic certainly cannot be separated from books, journals, or articles and papers. It is not too surprising that an academic has references with almost one workspace or more. Along with the development of technology, almost all scientific references have been converted into digital format in the form of documents/computer files. This is certainly very helpful so that reference storage no longer requires large or large physical space, but is enough to be stored on a palm-sized hard disk. The objectives of this PKM are: 1) Improving teacher skills in making reference publications through software;2) To support its implementation, the method offered is the provision of training materials on publication reference management.

Keywords: PKM, Publication Reference Management, MGMP

\section{PENDAHULUAN}

Lokasi wilayah mitra PKM ini yakni kelompok MGMP Matematika SMP adalah di Kabupaten Pangkep, Provinsi Sulawesi Selatan. Kabupaten Pangkep memiliki luas wilayah 12.362,73 $\mathrm{Km}^{2}$. Adapun batas wilayah Kabupaten Pangep ini adalah:

- Sebelah Utara berbatasan dengan Kabupaten Barru

- Sebelah Selatan berbatasan dengan Kabupaten Maros

- Sebelah Timur berbatasan dengan Kabupaten Bone

- Sebelah Barat berbatasan dengan Laut Jawa 
Di Kabupaten Pangkep terdapat 13 (Tiga Belas) Kecamatan dan salah satunya adalah kecamatan Pangkejene. Kecamatan Pangkajene ini memiliki 9 Kelurahan salah satunya adalah Tumampua, di Kelurahan Tumampua ini pula lokasi kampus STKIP Andi Matappa Pangkep dan lokasi Sekolah yang dijadikan mitra dalam kegiatan PKM ini. Adapun guru Matematika SMP baik yang berstatus PNS maupun Non PNS sekitar 90 orang.

Publikasi Ilmiah hasil penelitian dikalangan guru-guru masih tergolong rendah, karena kurangnya pengetahuan guru-guru akan publikasi artikel ilmiah dan jurnal-jurnal yang bisa menerima tulisan mereka. Hal ini bisa terlihat dari kurangnya guru yang mempublikasikan tulisan mereka pada jurnaljurnal pendidikan, khususnya matematika.

Salah satu kegiatan yang penting dalam menjalankan tugas kita sebagai tenaga pengajar adalah melakukan publikasi ilmiah. Melakukan sitasi terhadap sumber referensi merupakan bagian tidak terpisahkan dalam publikasi ilmiah. Mengumpulkan referensi, membacanya, serta memasukkannya ke dalam naskah kita merupakan tugas yang cukup menyita waktu dan tenaga. Dahulu, para penulis menggunakan kartu index untuk menyimpan informasi referensi yang digunakan dalam naskah. Disinilah peranan dari perangkat lunak reference manager, yaitu melakukan digitalisasi koleksi referensi, sehingga aktifitas seperti pengelolaan dan pencarian dapat dengan mudah dilakukan. Generasi pertama dari reference manager sudah tersedia sejak lebih dari 25 tahun yang lalu, seperti Endnote dan BibTeX/LaTeX yang masih populer hingga kini. Namun penulisan sitasi pada perangkat lunak tersebut masih dilakukan secara manual. Saat ini kita memiliki banyak pilihan perangkat lunak reference manager, mulai dari yang bersifat open source hingga yang proprietary.

Publikasi artikel imliah kelompok MGMP Matematika SMP di Kabupaten Pangkep masih tergolong rendah, karena masih jarangnya ditemukan guru yang mempublikasikan hasil penelitiannya ke dalam jurnal-jurnal pendidikan, khususnya matematika. Sehingga minat guru-guru dalam mempublikasikan hasil penelitiannya termasuk rendah dibandingkan dengan kabupaten lain.

Dalam dunia penulisan ilmiah, kejujuran merupakan salah satu tolak ukur kualitas. Untuk memperlihatkan kejujuran tersebut, penulis akan merujuk kepada sekian banyak bahan bacaan dan menampilkan sebagian kalimat sebagai pernyataan penulis lain yang mendukung ide dalam tulisannya. Keberadaan referensi pada tulisan ilmiah merupakan sebuah keharusan dalam karya ilmiah. Referensi merupakan aspek yang sangat penting dalam dunia akademis.Seorang akademisi tentunya tidak dapat dipisahkan dari buku, jurnal, artikel dan makalah.Tidak terlalu mengherankan bila seorang akademisi memiliki referensi dengan jumlah hampir satu ruangan kerja bahkan lebih (Handoko, 2016). Di samping faktor buku, jurnal atau karya ilmiah lain terlewatkan, faktor Inkonsisten penulisan juga sering dijumpai pada saat penulisan bibliografi. Seringkali penulis menulis kota penerbit sebuah buku sebelum nama penerbit pada satu kutipan bibliografi, namun pada kutipan lain kota penerbit ditulis setelah nama penerbit buku. Hal tersebut juga dijumpai terhadap aturan penulisanpenulisan author, volume jurnal dan halaman yang tidak konsisten ditulis dalam satu bibliografi. Hal lain yang sering terjadi, ketika penulis buku mengadakan pengeditan terhadap karya tulisnya. Sebagai contoh penulis menghapus suatu baris atau kalimat karena di rasa tidak pas dengan alasan lain. Secara otomatis sumber rujukan seperti author dan tahun dihapus. Namun penulis terkadang lupa untuk menghapus di bagian bibliografi, sehingga mengakibatkan, ada satu atau dua buah kutipan di bibliografi yang tertulis tapi tidak dapat ditelusur di 
bagian in text. Untuk menghindari hal tersebut di atas, maka penulis suatu karya ilmiah yang banyak melakukan penyitiran, sangat disarankan melakukan manajemen referensi. Dalam melakukan manajemen referensi sekarang ini penulis banyak dibantu dengan kehadiran-kehadiran piranti lunak untuk manajemen referensi. Masing-masing piranti lunak manajemen referensi tersebut punya kelebihan dan kekurangan tersendiri.

Referensi merupakan hal yang paling penting bagi calon penulis dalam mengembangkan tulisannya.Tulisan yang baik dapat dinilai dari referensi yang digunakan.Pencarian dan pengumpulan referensi membutuhkan waktu yang lama dan tenaga yang cukup besar dengan tingkatan dan konsentrasi yang tinggi untuk menulis sumber tulisan agar tidak disebut plagiat.

Sebagai Mitra dalam kegiatan PKM ini, Kelompok MGMP Matematika SMP di Kabupaten Pangkep menemukan bahwa kebanyakan guru-guru Matematika belum mampu memanfatkan adanya jurnal-jurnal pendidikan yang dapat menerbitkan tulisan atau hasil penelitian mereka. Bahkan menurut wawancara pengusul dengan ketua Kelompok Mitra, hampir 8o \% dari guru-guru Matematika yang ada di Kabupaten Pangkep tidak meneritkan hasil tulisannya. Sehingga semangat menulis dan meneliti tergolong rendah.

Beberapa permasalahan yang terindetinfikasi berkaitan dengan rendahnya semangat menulis dan publikasi guru Matematika SMP dapat diuraikan sebagai berikut:

a. Guru-guru Matematika SMP masih kurang memiliki sumber-sumber informasi jural-jurnal yang dapat menerbitkan tulisan mereka.

b. Belum adanya sosialisasi maupun pelatihan baik dari pemerintah pusat maupun pemerintah daerah tentang publikasi ilmiah.

Berdasarkan masalah di atas, maka ditawarkan beberapa alternative pemecahan masalah tersebut sebagai berikut:

1. Menyediakan sumber belajar seperti panduan publikasi ilmiah menggunakan software

2. Melatih guru memanfaatkan/menggunakan software manajemen referensi

3. Mengadakan pelatihan manajemen referensi publikasi bagi guru-guru matematika

\section{METODE PELAKSANAAN}

Adapun tahapan atau langkah-langkah pelaksanaan program sebagai solusi untuk permasalahan mitra dapat dilihat dari diagram berikut:

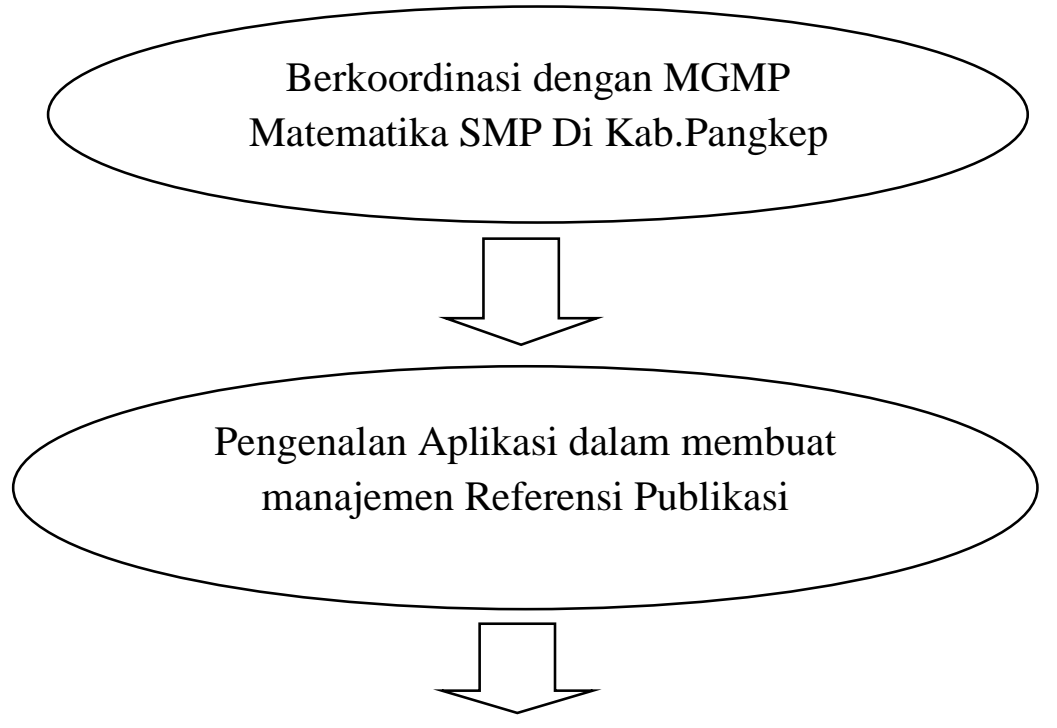




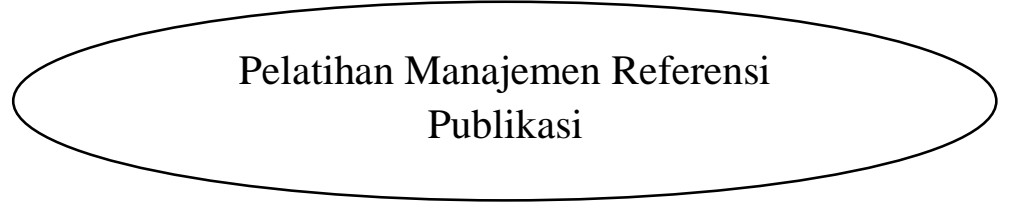

Gambar 1. Bagan Alir Tahapan Pelaksanaan Program

\section{HASIL DAN PEMBAHASAN}

Kegiatan ini bermitra dengan Ketua MGMP Matematika Kabupaten Pangkep. Selama pelaksanaan kegiatan pengabdian ini yang berlangsung di bulan September 2020. Adapun hasil kegiatan yang dicapai dalam kegiatan pengabdian ini adalah:

\section{Tahap 1. Berkoordinasi dengan MGMP Matematika SMP Di Kab.Pangkep}

Pelaksana program berkoordinasi dengan Ketua dan Pengurus kelompok MGMP Matematika SMP di Kabupaten Pangkep berkaitan dengan kegiatan pelatihan, utamanya mengenai tempat dan waktu pelaksanaan kegiatam. Pelaksanaan pelatihan ini direncanakan pada Bulan September 2020. Pengurus MGMP SMP Matematika Kab.Pangkep diharapkan dapat membantu pelaksana dalam menyiapkan sarana dan prasarana penunjang pelaksanaan kegiatan pelatihan ini. Seperti halnya penyampaian surat menjadi peserta dalam pelaksanaan pelatihan ke anggota kelompok MGMP Matematika SMP di Kab. Pangkep. Selanjutnya jumlah guru-guru Matematika yang diundang sebanyak 30 orang yang berasal dari beberapa SMP yang ada di Kabupaten Pangkep.

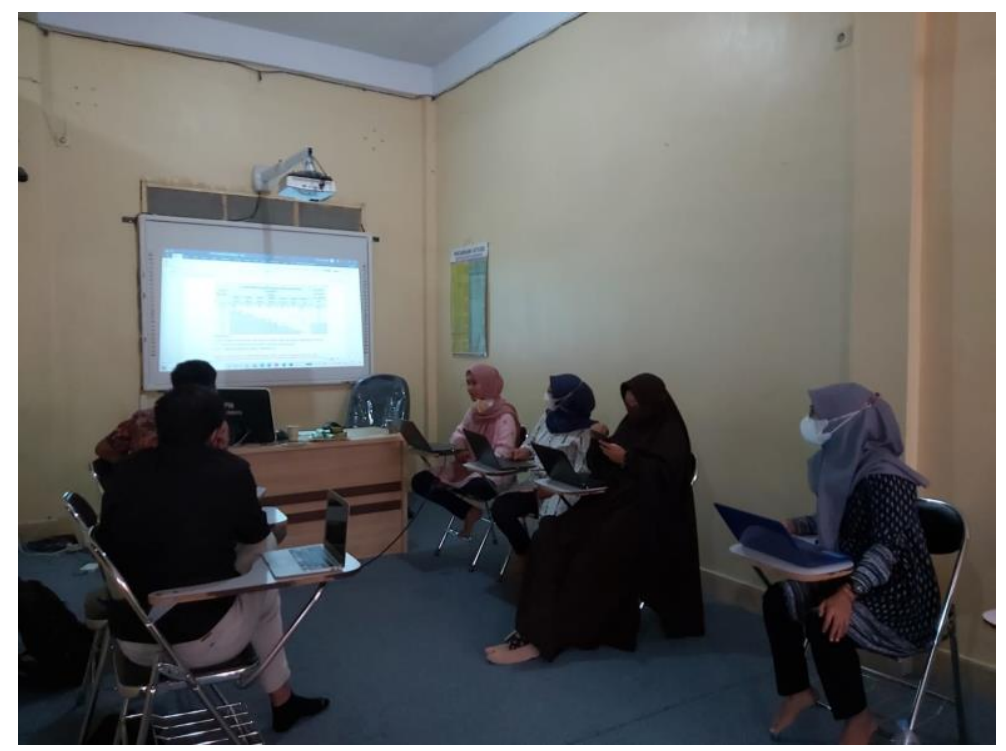

Gambar 2. Koordinasi dengan MGMP Matematika SMP 


\section{Tahap 2. Pengenalan Aplikasi Mendeley}

Kegiatan Pelatihan ini diawali dengan pengenalan tentang aplikasi yang akan digunakan dalam membuat manajemen referensi publikasi yaitu mendeley. Mendeley adalah sebuah perangkat lunak yang kelahirannya diilhami oleh sebuah upaya untuk mengintegrasikan "citation \& reference manager" ke dalam sebuah jejaring sosial. Dengan jejaring semacam ini, peneliti di berbagai belahan dunia dapat berkolaborasi dan melakukan sharing data penelitian. Perangkat lunak Mendeley saat ini tersedia dalam 2 (dua) versi, Desktop Edition dan Institutional Edition. Mendeley Desktop Edition (selanjutnya dalam panduan ini akan disebut Mendeley saja) adalah perangkat lunak "citation \& reference manager" yang bisa didapatkan secara gratis (tidak berbayar) dan sangat kompatibel dengan program pengolah kata MS Word (2003,2007,2010), Mac Word (2008, 2011), Open Office/Libre Office (3.2), dan Bib Tex. Beberapa fitur yang menjadi andalan Mendeley antara lain:

- Dapat berjalan pada MS Windows, Mac, ataupun Linux.

- Menampilkan metadata dari sebuah file PDF secara otomatis.

- Backup dan sinkronisasi data dari beberapa komputer dengan akun online.

- Smart filtering dan tagging.

- PDF viewer dengan kemampuan anotasi dan highlighting.

- Impor dokumen dan makalah penelitian dari situs-situs eksternal (misalnya PubMed, Google Scholar, arXiv, dll).

- Integrasi dengan berbagai perangkat lunak pengolah kata seperti MS Word, Open Office, dan Libre Office.

- Fitur jejaring sosial.

- iPhone dan iPad app.

- Free web storage sebesar $2 \mathrm{~GB}$ yang dapat dimanfaatkan sebagai online backup.

Disamping itu, pengaturan dan manajemen file hasil download sangat mudah dilakukan dengan "drag and drop", sehingga terasa sangat user friendly. Namun demikian bukan berarti Mendeley tidak memiliki kelemahan. Mendeley akan mengunggah semua file yang ada di hard disk lokal ke web site Mendeley, sehingga apabila file-file ini kita dapatkan dari jurnal berbayar seperti ScienceDirect, ProQuest, Clinical Key tentunya akan sedikit bermasalah khususnya dengan hak akses terhadap file-file tersebut. 


\section{Tahap 3. Pelatihan Manajemen Referensi Publikasi}

Pada tahapan ini, para peserta diperlihatkan langsung cara membuat daftar referensi dalam publikasi ilmiah, dimulai dari penginstakan aplikasi, membuat library dalam aplikasi, mengelola dokumen dan referensi, membuat sitiran dan daftar pustaka, dan membuat daftar pustaka. Setiap peserta pelatihan akan disiapkan unit komputer masing-masing dan selanjutnya diberikan latihan penggunaan aplikasi tentu dengan media komputer. Jadi tiap peserta dapat mempraktikkan langsung setiap langkah yang disampaikan dalam materi pelatihan.

\section{Instalasi Mendeley.}

Proses instalasi Mendeley sangatlah mudah. Langkah-langkah berikut ini memperlihatkan proses instalasi perangkat lunak Mendeley ke dalam komputer. Membuat Akun Mendeley

a. Jalankan web browser yang Anda gunakan, dan akses laman web http://www.mendeley.com

b. Klik "sign up $\mathcal{E}$ download" untuk memulai proses membuat akun Mendeley sekaligus mengunduh perangkat lunaknya. Akun Mendeley juga dapat dibuat menggunakan akun facebook yang Anda miliki.

c. Ketikkan nama depan, nama belakang, dan juga alamat email Anda. Kemudian klik "create free account".

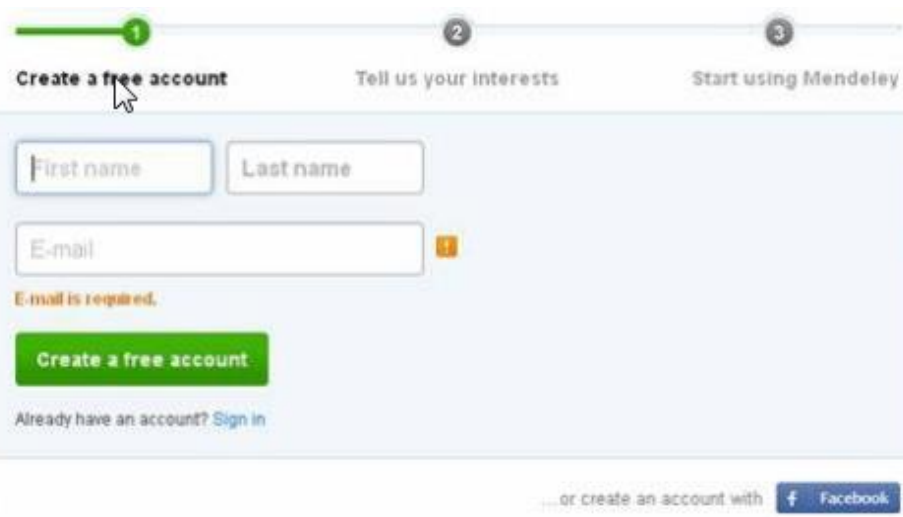

d. Tahap berikutnya:

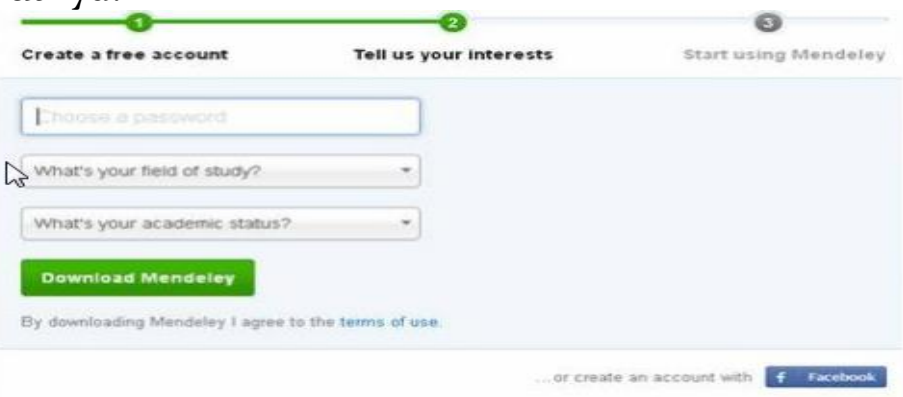


- Choose a password : tuliskan password yang Anda ingin pergunakan.

- What's your field of study? : pilih disiplin ilmu yang sesuai dengan minat, misal: medicine

- What's your academic status? : pilih status akademik atau profesi Anda.

Klik “download mendeley” untuk memulai proses mengunduh aplikasi Mendeley Desktop.

\section{Menginstal Perangkat Lunak Mendeley}

a. Klik dua kali file Mendeley-Desktop-1.8.4-win32 yang telah diunduh. Setup Wizard akan mengarahkan Anda untuk menyelesaikan proses instalasi Mendeley Desktop.

b. Klik next untuk memulai Setup Wizard.

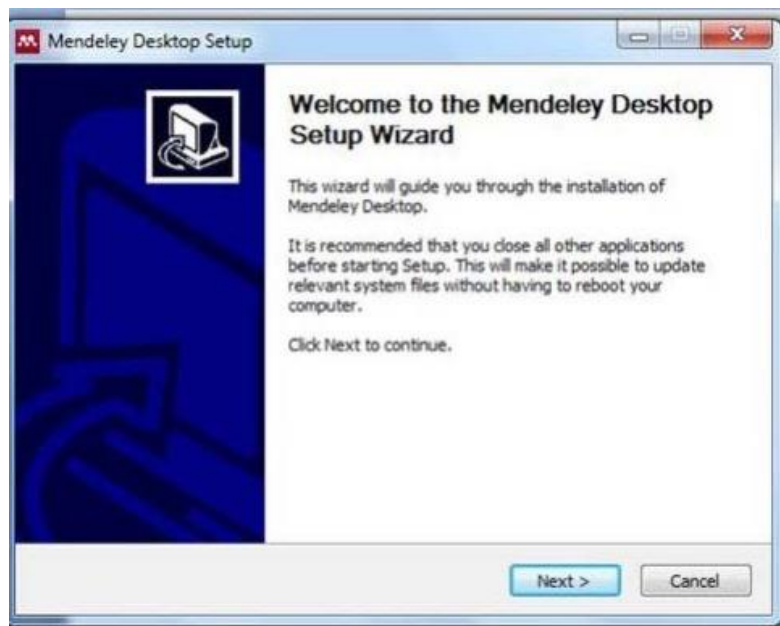

c. Klik "I Agree" jika setuju dengan License Agreement yang disodorkan oleh Mendeley.

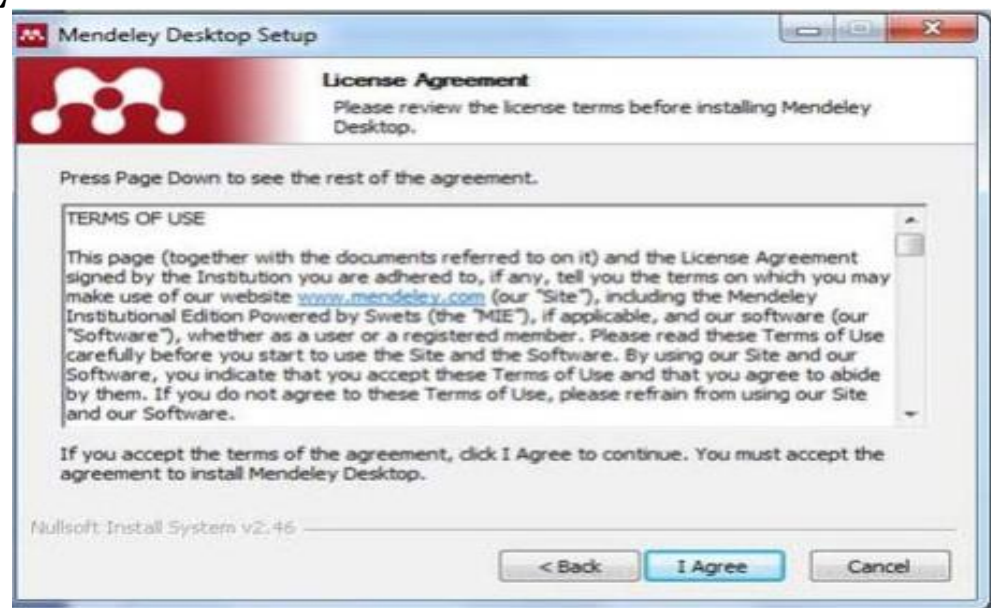

d. Klik "Browse" untuk menyesuaikan di folder mana aplikasi akan dipasang. Anda dapat mengabaikan pilihan tersebut dan langsung klik "next" untuk melanjutkan ke tahapan berikutnya. 


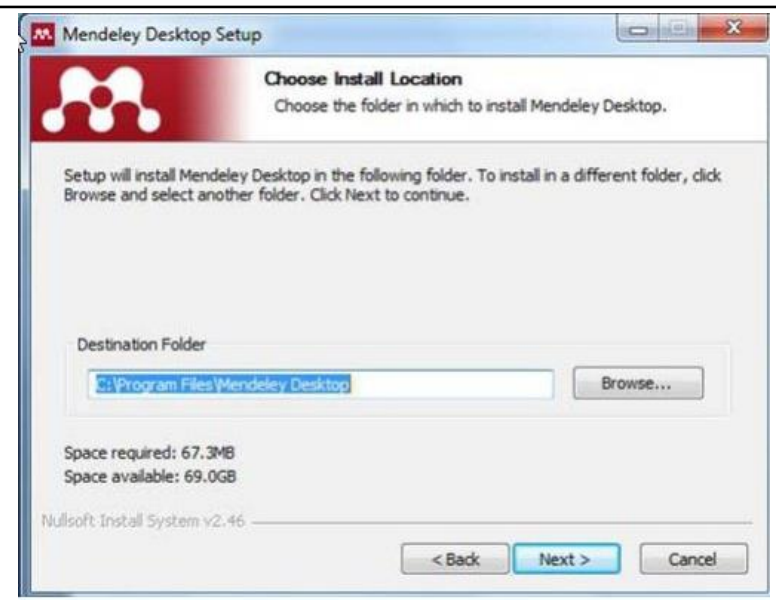

e. Klik Install untuk memulai proses instalasi Mendeley Desktop.

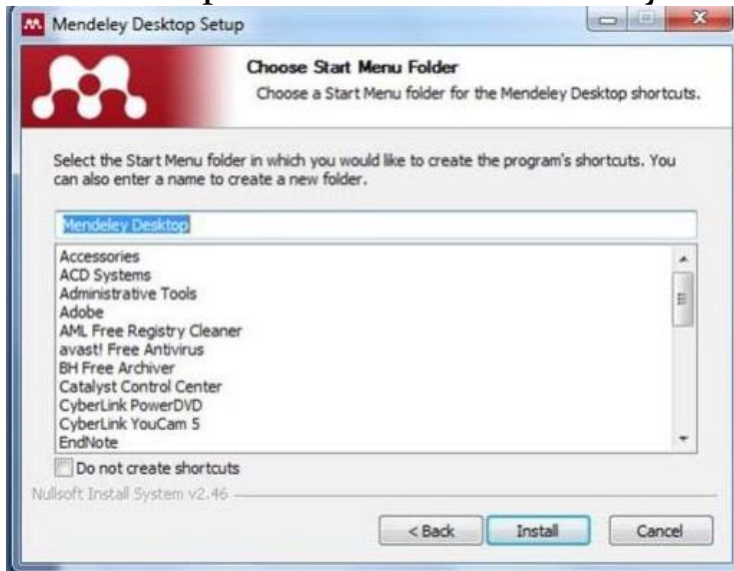

f. Beri tanda centang pada Run Mendeley Desktop dan klik "finish" untuk menyempurnakan proses instalasi.

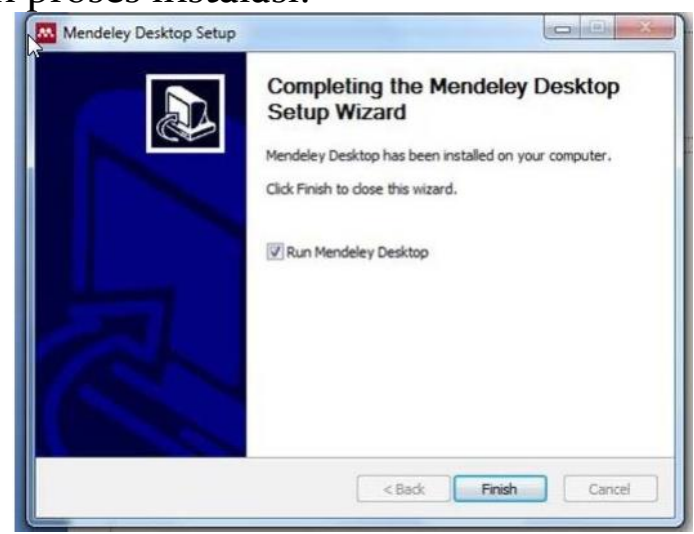

Sampai disini proses instalasi Mendeley Desktop telah selesai. 
E-ISSN: 2776-3331

Vol. 1, No. 2, pp. 142-161

November, 2021

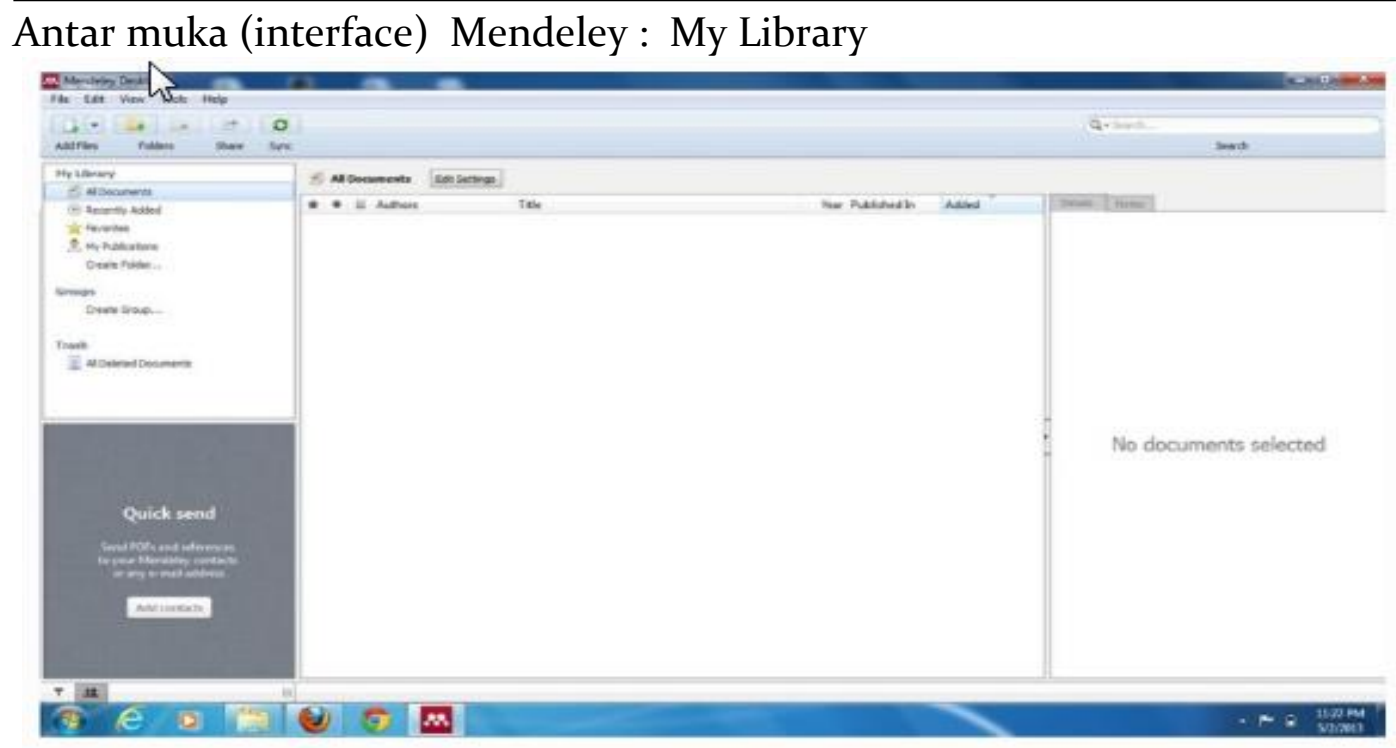

Interface Aplikasi Mendeley Desktop terdiri atas 3 bagian,

1. Kolom sebelah kiri (left panel), menampilkan seluruh sumber daya (koleksi referensi) yang Anda miliki. My Library terbagi ke dalam folder dan kelompok. Beberapa folder secara otomatis disediakan oleh Mendeley, seperti: "recently added, favorities".

2. Kolom tengah (central panel), dipergunakan untuk menampilkan rincian daftar sumber daya referensi yang dipilih pada kolom kiri.

3. Kolom sebelah kanan (right panel), dipergunakan untuk menampilkan detail informasi dari koleksi terpilih di kolom tengah.

Sedangkan "toolbar" berisi ikon untuk tugas-tugas yang bersifat umum, seperti menambah dan menghapus dokumen, melakukan sinkronisasi dan sebagainya. Anda juga dapat melakukan 'drag and drop" maupun "right click”.

\section{Membangun Library dalam Mendeley}

\section{Menambahkan Dokumen}

Klik icon Add file pada menu bar untuk menambahkan dokumen ke dalam Mendeley. 


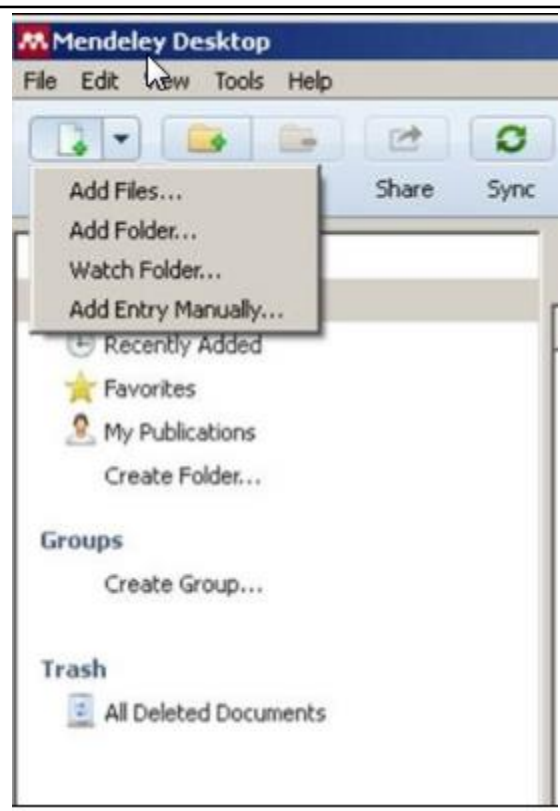

- add file: untuk menambahkan dokumen satu per satu

- add folder : menambahkan dokumen satu folder sekaligus

- watch folder : penambahan dokumen dalam folder secara otomatis akan ditambahkan ke dalam Mendeley

- add entry manual : menambahkan (input) data secara manual.

Pilih file dokumen (PDF, RTF, Doc) yang akan ditambahkan ke dalam library Mendeley. Klik Open untuk menyelesaikan proses penambahan.

TIPS: Drag and drop file PDF ke dalam jendela Mendeley akan mempercepat pekerjaan anda.

Import dan Export Citation

\section{a. Import Citation dari JSTOR}

- Berikan tanda centang pada setiap artikel dalam JSTOR yang ingin ditambahkan sitasinya ke dalam library.

- Klik icon Import to Mendeley pada menu bar browser Anda.

- Klik Import pada tampilan menu berikutnya untuk memulai proses import data ke Mendeley.

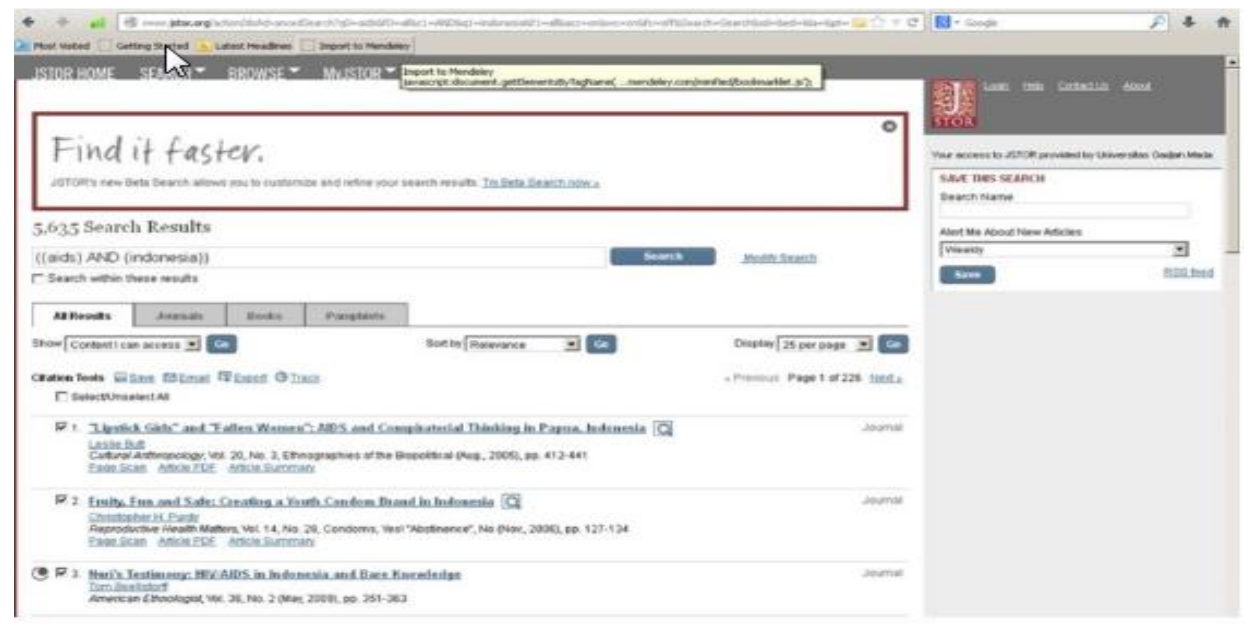


E-ISSN: 2776-3331

Vol. 1, No. 2, pp. 142-161

November, 2021

\section{Import Citation dari Google Scholar}

Google scholar (Google Cendekia) memiliki fasilitas atau fitur untuk ekspor citation ke dalam format EndNote, BibTex., RefMan, dan RefWorks. RefMan dapat dipilih untuk memudahkan ekspor citation ke reference manager yang digunakan, termasuk Mendeley Desktop. Sayangnya fitur ini tidak secara otomatis aktif sehingga perlu diaktifkan terlebih dahulu. Untuk mengaktifkan fitur ini, klik terlebih dahulu menu "setting" yang terletak di pojok kanan atas halaman web Google Scholar.

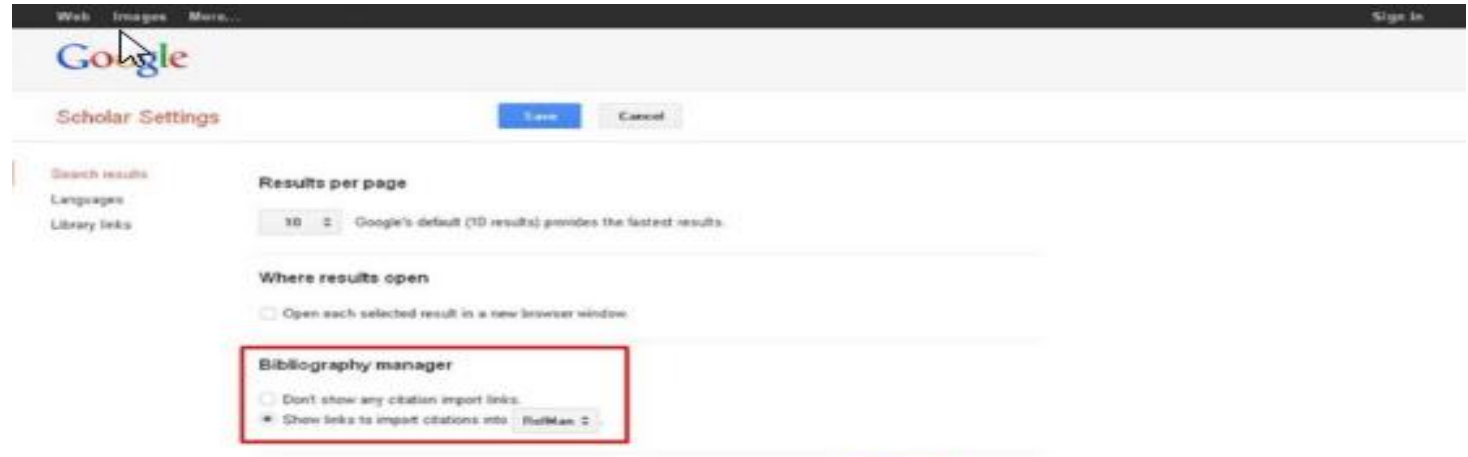

- Masukkan keyword yang ingin dicari pada kotak/kolom pencarian Google search.

- Tentukan artikel yang akan diimpor data sitasinya, kemudian klik link Import to Refman yang ada di bawah judul artikel

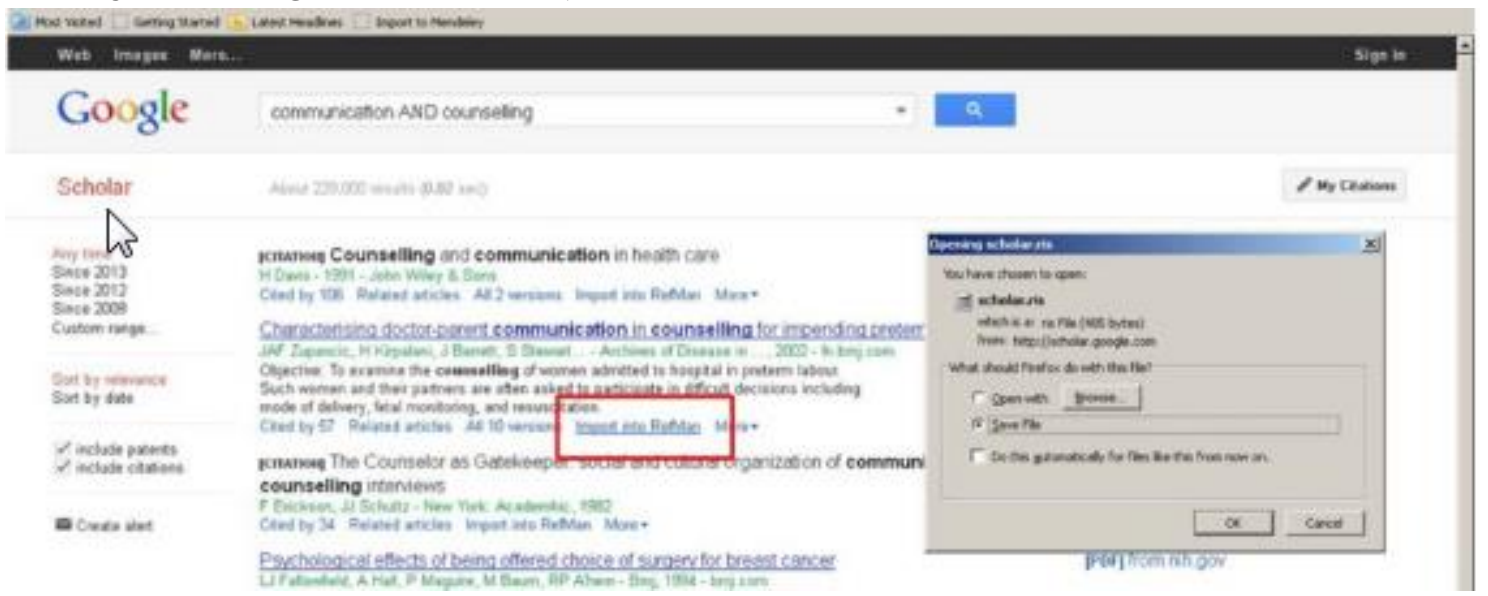

TIPS :

- Pastikan referensi yang akan Anda sitir memiliki permanent address seperti DOI, ArXiv, PMID sehingga terhindar dari penggunaan referensi yang tidak akurat.

- Pastikan referensi yang diunduh berasal dari direktori atau database yang valid, seperti ERIC, JSTOR, DOAJ, EBSCOhost, ProQuest, dll.

\section{Export Citation dan Abstract dengan Format RIS}

- Masukkan keyword untuk artikel yang ingin Anda cari pada database ScienceDirect.

- Berikan tanda centang pada artikel yang terpilih untuk diekspor sitasinya. 


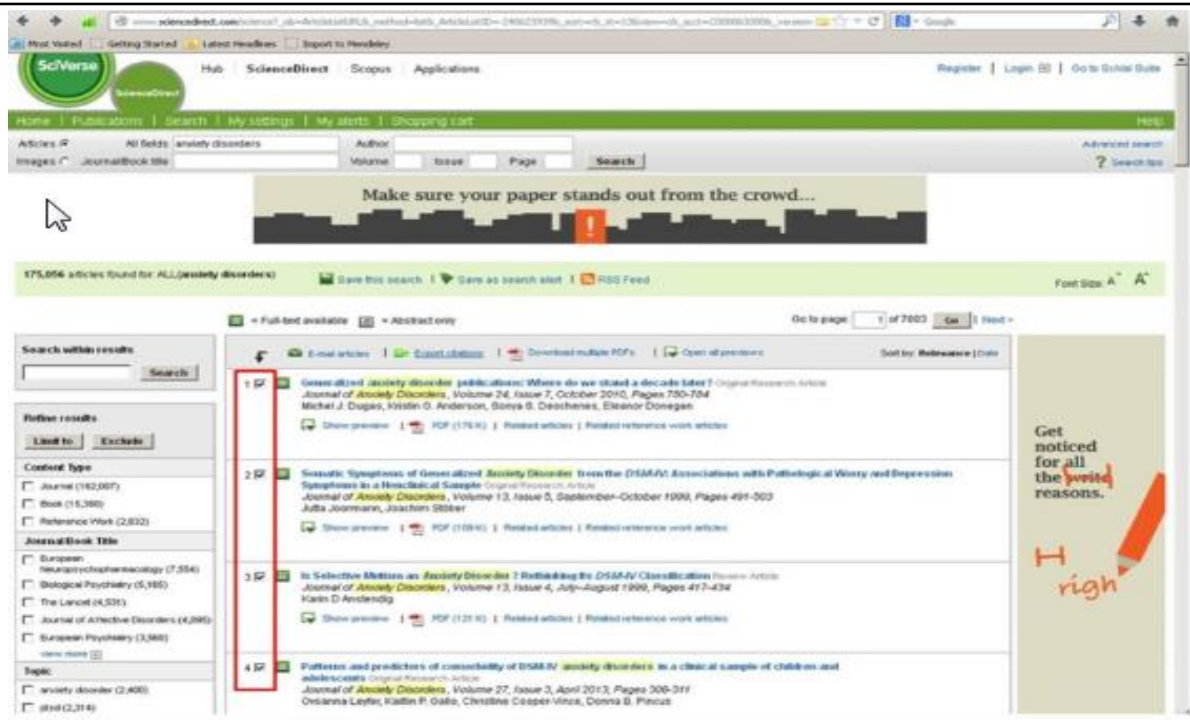

- Pada tahapan berikutnya, database ScienceDirect akan meminta kita untuk menentukan:

- Content format : apakah hanya sitasi saja ataukah sitasi dan abstrak

- Export format : pilih RIS Format agar datanya bisa dibaca oleh Mendeley

- Klik export untuk memulai proses.

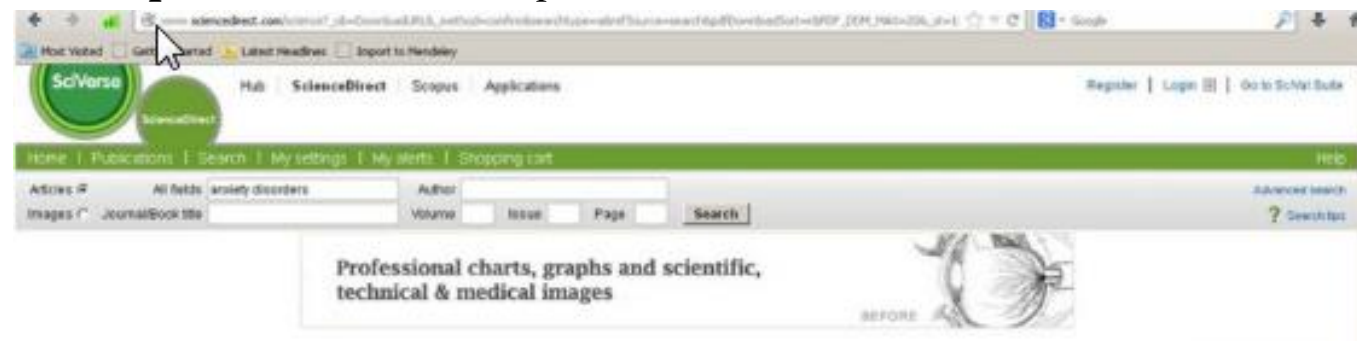

Expert citations
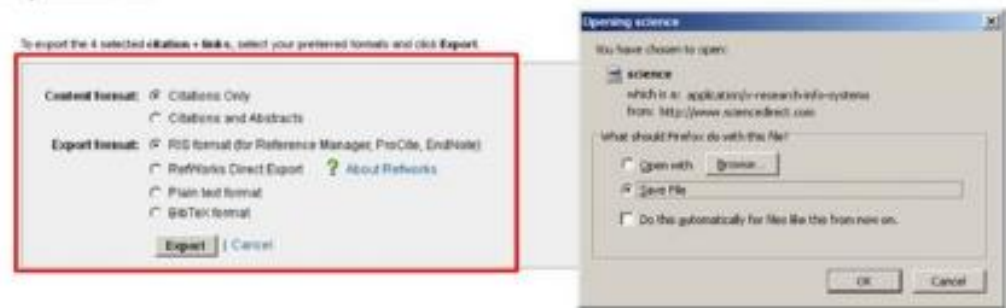

your promote

your work

published.

Bertukar data dengan perangkat lunak "citation \& reference manager" yang berbeda.

Mendeley memiliki fasilitas untuk saling bertukar library dengan perangkat lunak manajemen referensi lainnya, seperti EndNote dan Zotero. Karena format standar file yang digunakan masing-masing perangkat lunak berbeda, maka kita dapat mengekspor data (library) ke dalam format Extensible Markup Language (XML) atau Research Information Systems (RIS) yang lebih umum dipakai untuk pertukaran data citation.

\section{Bertukar data dengan EndNote}

Agar Mendeley dapat membaca data yang dikelola dengan perangkat lunak EndNote, ikuti langkah-langkah seperti berikut :

Pada perangkat lunak EndNote 
E-ISSN: 2776-3331

Vol. 1, No. 2, pp. 142-161

November, 2021

- Buka menu File dan pilih Export.

- Pada jendela export file name yang muncul, pilih XML atau RIS untuk opsi Save as Type.

- Klik Save untuk memulai ekspor data dan menyimpannya ke dalam komputer.

Export file name:

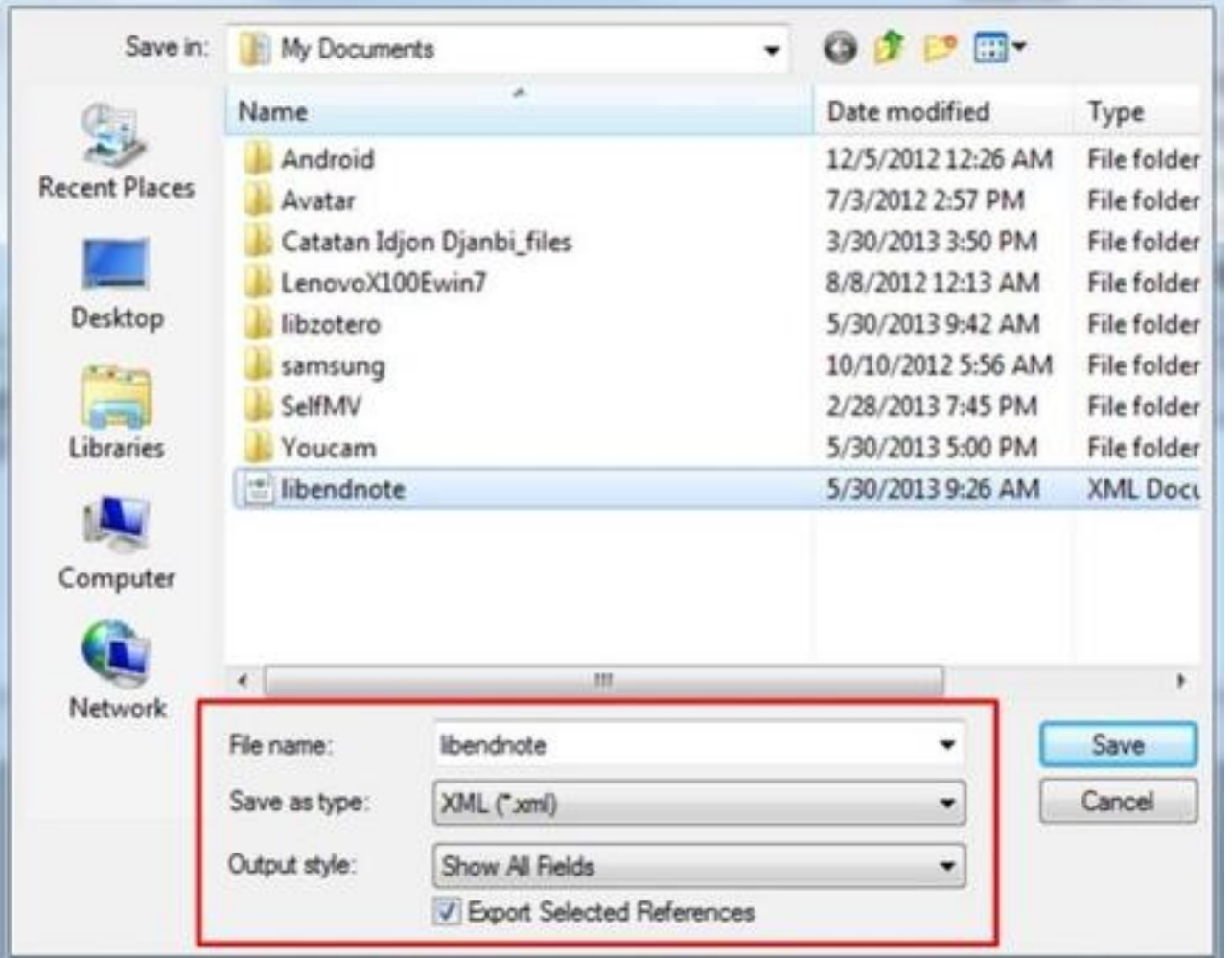

Pada perangkat lunak Mendeley Desktop.

- Buka menu File dan pilih Import... $\rightarrow$ EndNote XML

- Pada jendela Add Files yang muncul, pilih file hasil eskpor dari EndNote (.xml)

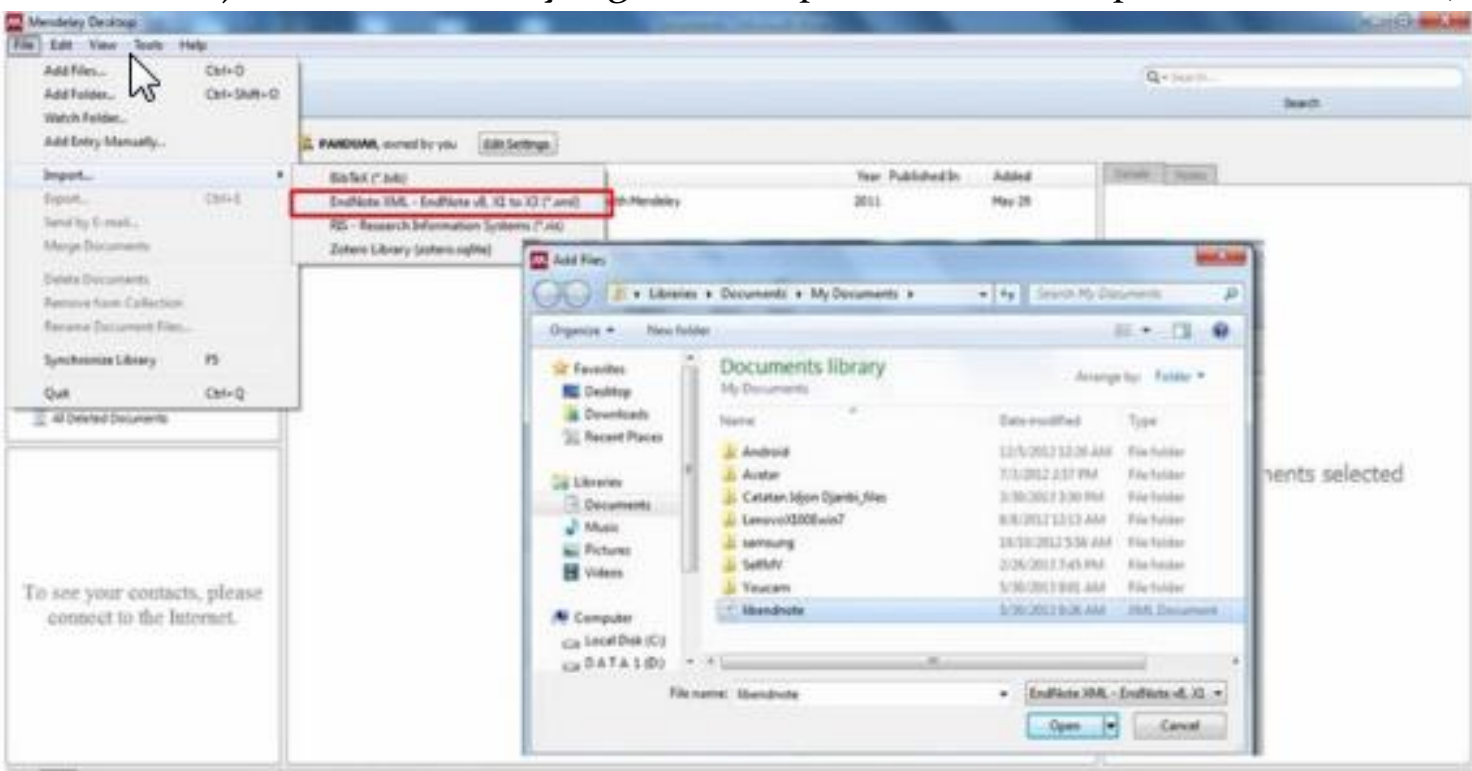

- Klik Open, dan Mendeley akan menambahkan data citation dari EndNote tersebut ke dalam library. 


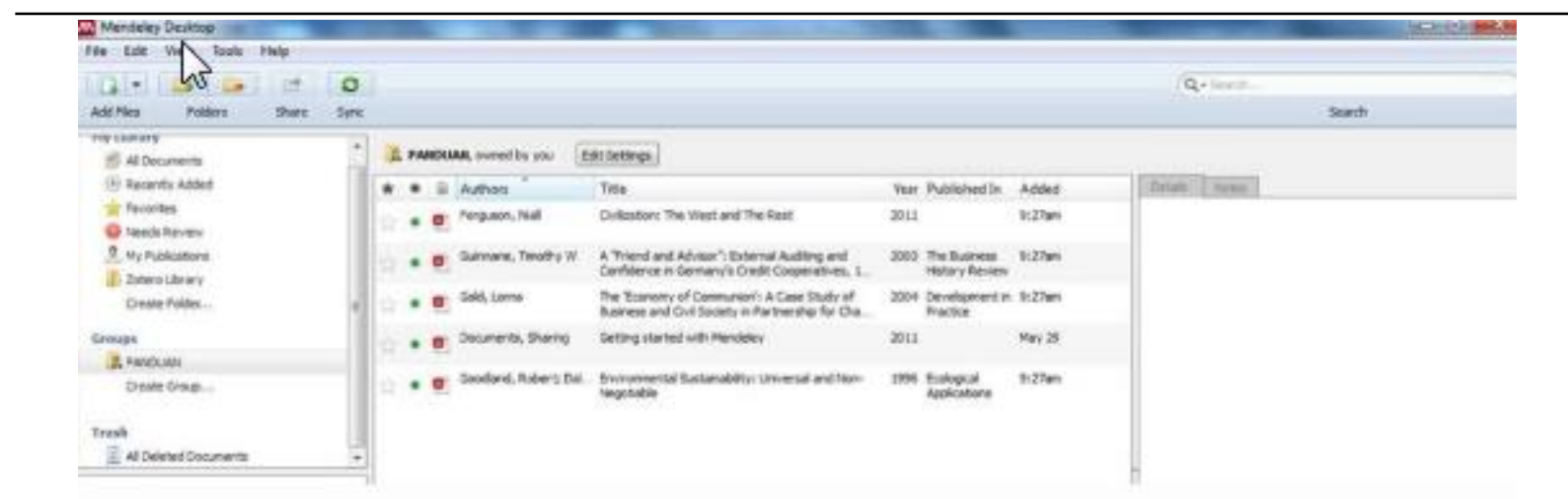

\section{Bertukar data dengan Zotero}

Mendeley dapat dengan mudah mengintegrasikan data yang ada di Zotero ke dalam sistem Mendeley.

- Buka menu Tools pada Mendeley, kemudian pilih Option.

- Pada jendela Option yang muncul kemudian, pilih tab "Zotero/CiteUlike”.

- Beri tanda centang pada bagian Zotero Integration, dilanjutkan klik "Apply”.

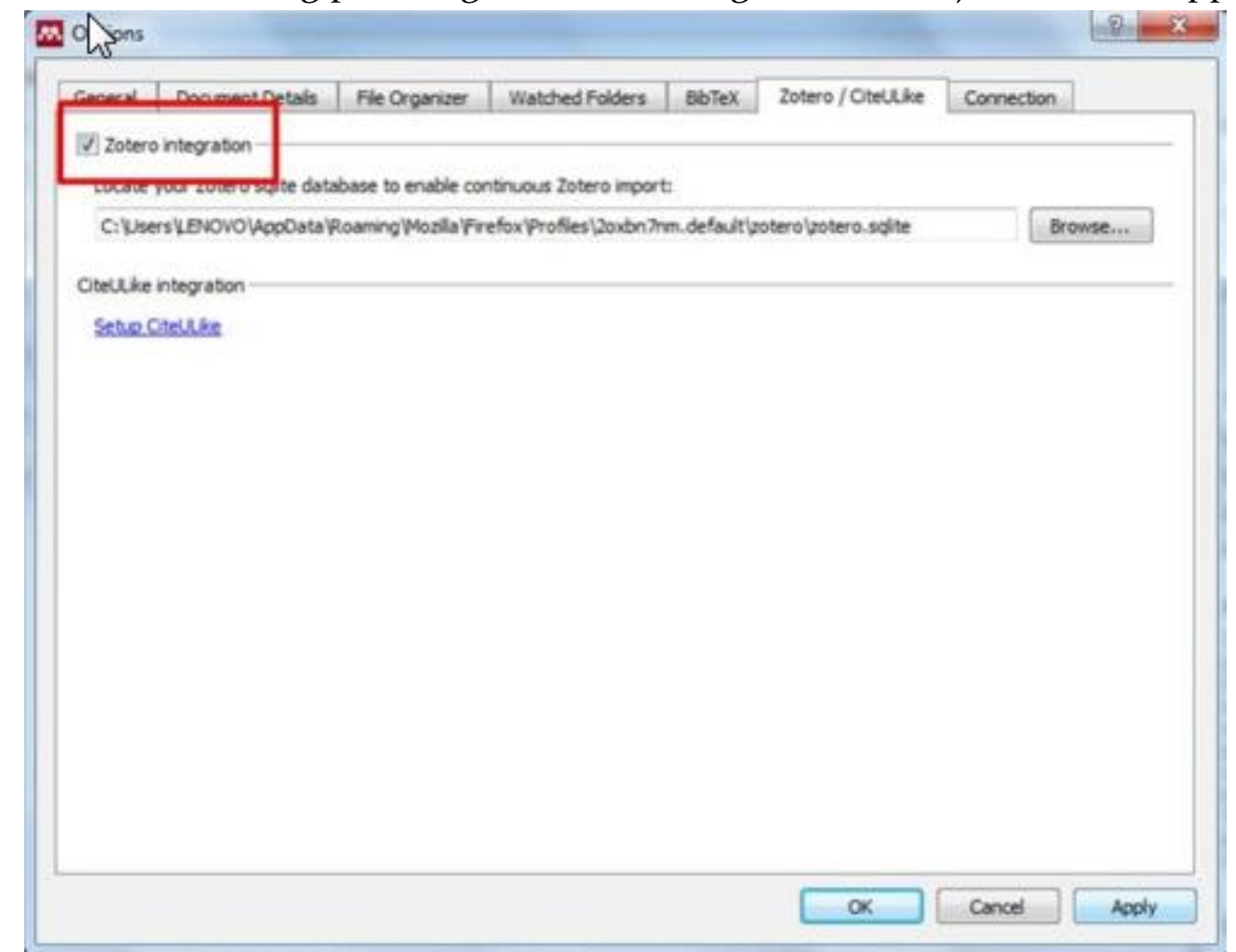

Secara otomatis data pada Zotero akan terintegrasikan dengan Mendeley. Setiap penambahan data pada Zotero akan ditambahkan pula ke dalam library Mendeley.

Sinkronisasi ke dalam Mendeley Web.

Mendeley memiliki fitur sinkronisasi file yang sangat bermanfaat ketika kita bekerja dengan banyak perangkat yang berbeda. Dengan mengaktifkan fitur sinkronisasi ini, maka file-file PDF yang kita miliki dalam Mendeley akan disimpan juga dalam web server Mendeley sehingga dapat diakses dari tempat atau perangkat yang berbeda. Untuk menjalankan sinkronisasi file ke dalam Mendeley Web, ikuti langkah berikut ini:

- Pilih “all documents" pada panel My Library (left panel). 
E-ISSN: 2776-3331

Vol. 1, No. 2, pp. 142-161

- Pilih "edit settings"

- Atur "synchronization options" sesuai dengan kebutuhan.

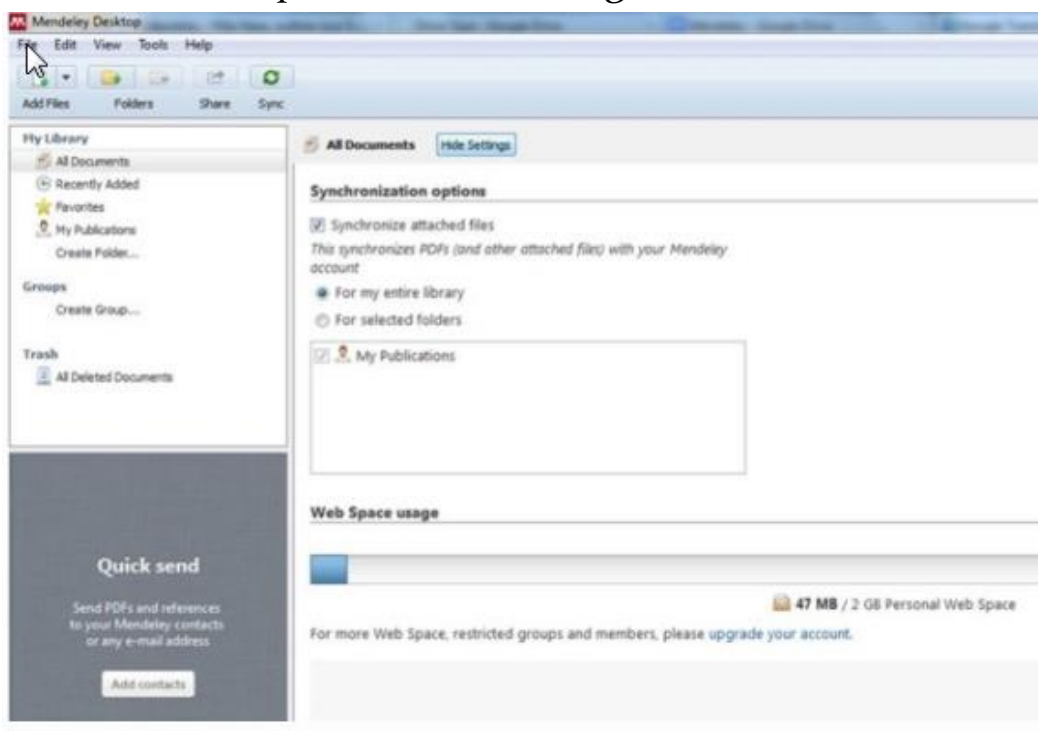

- Klik "Save E Sync".

Atau

- Jalankan Mendeley desktop

- Klik 'Sync Library'

\section{An Mendeley Desktop}

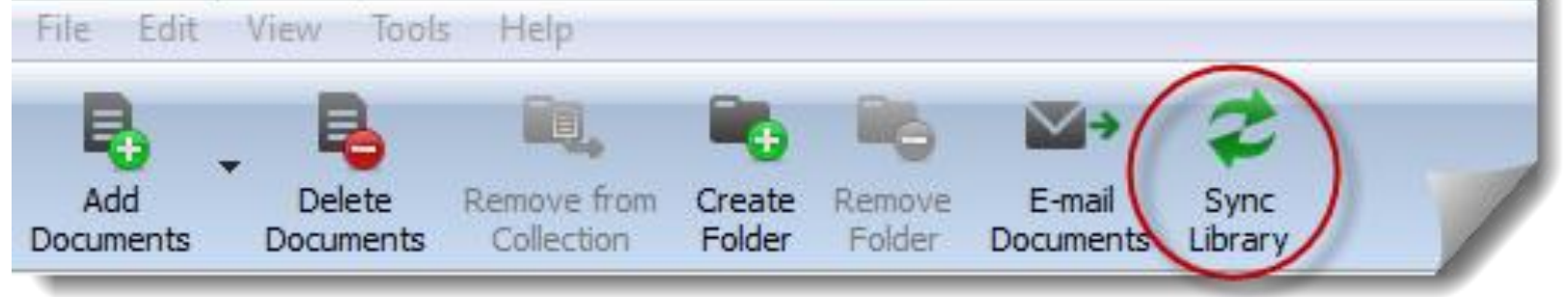

Login ke dalam akun Mendeley Web untuk melihat hasilnya

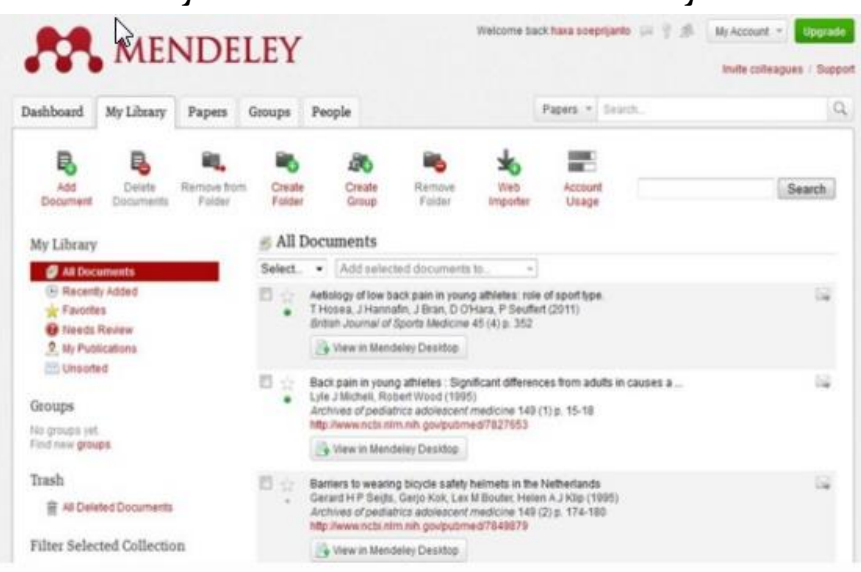

Sarana penelusuran di Mendeley

1. Paper - Untuk menelusur referensi

2. Group - untuk mencari research group

3. People - Untuk mencari 
E-ISSN: 2776-3331

Vol. 1, No. 2, pp. 142-161

November, 2021

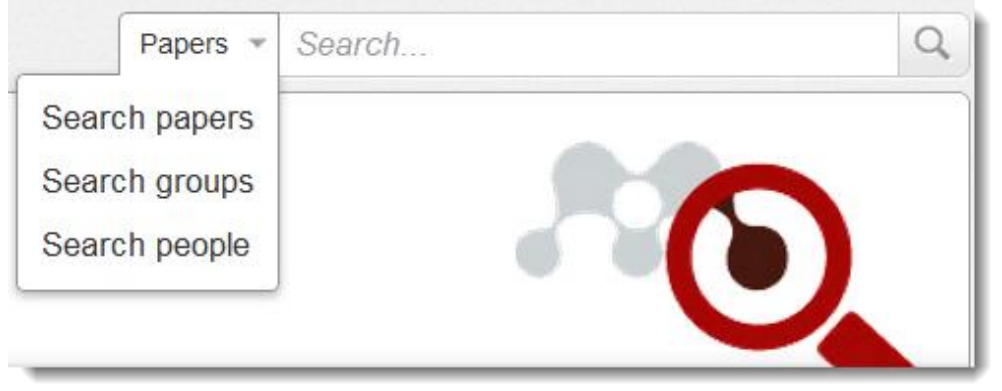

Menyimpan referensi ke Mendeley library di Web

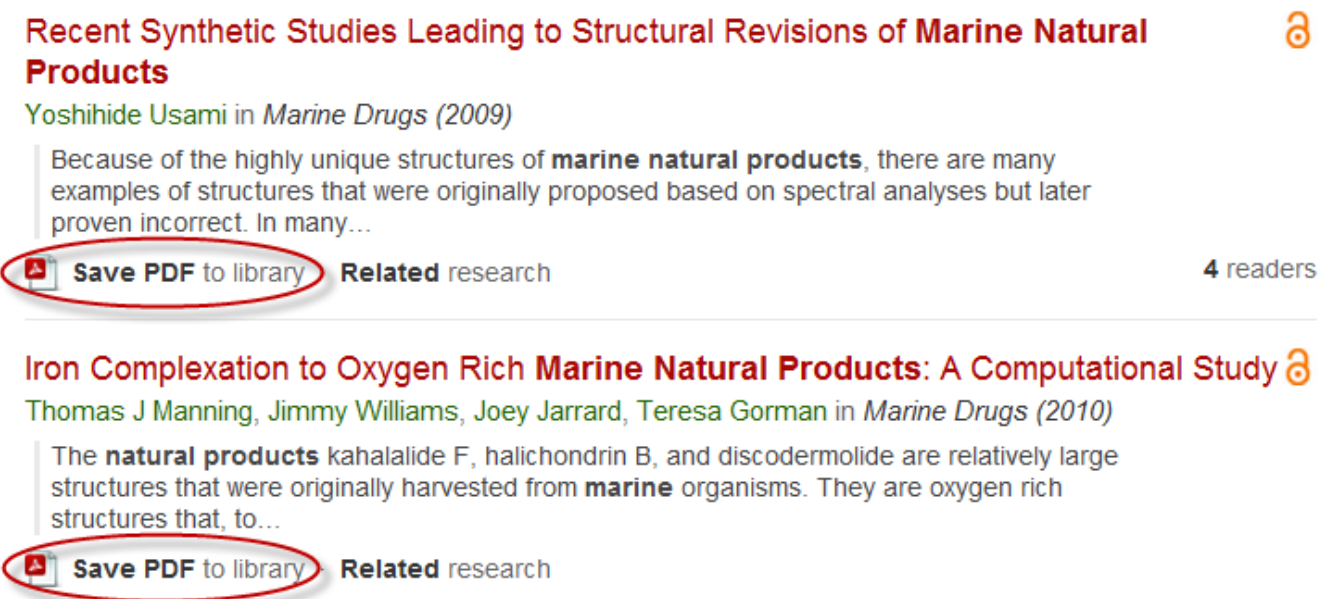

\section{Mengelola Dokumen dan Referensi}

\section{a. Membuat Folder}

- Arahkan kursor pada My Library (left panel) dan klik All Document.

- Klik icon Create New Folder pada menu bar.

Ketikkan nama folder yang Anda buat dan tekan enter.

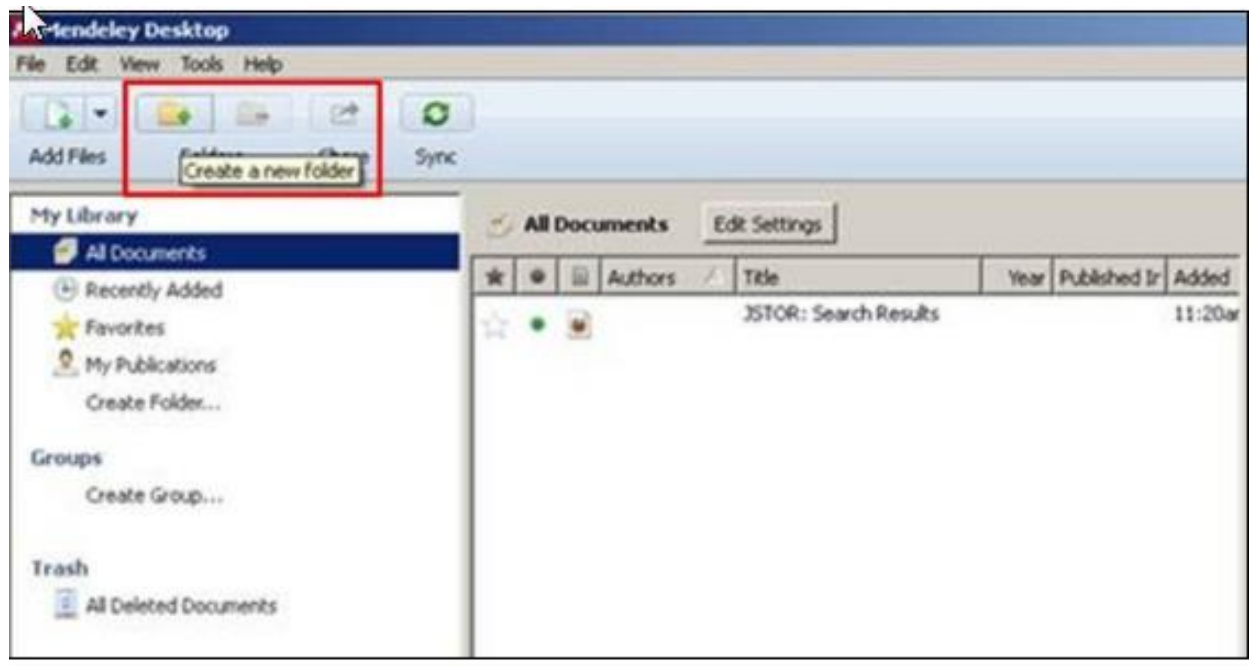

\section{Catatan:}

Folder dan sub folder dibuat untuk mengumpulkan dokumen yang memiliki kesamaan topik bahasan.

\section{b. Pencarian Pintar}

Mendeley memiliki fasilitas pencarian pintar untuk memudahkan proses temu kembali referensi yang kita inginkan. Pencarian pintar (smart searching) akan menandai 
E-ISSN: 2776-3331

Vol. 1, No. 2, pp. 142-161

November, 2021

(highlight) kata atau frasa di dalam artikel yang sesuai dengan istilah yang diketikkan di dalam kolom pencarian.

- Ketikkan pada kotak pencarian, kata yang akan gunakan sebagai dasar pencarian artikel.

- Tekan tombol Enter untuk memulai pencarian.

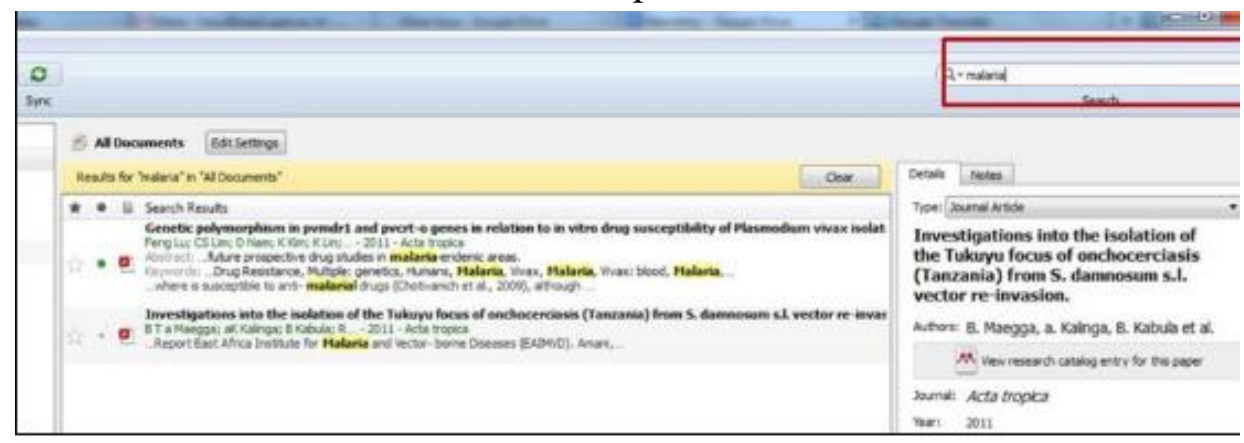

c. Membaca dan Menambahkan Catatan Penting

Kita dapat menandai (highlighting) teks atau paragraf pen ting pada artikel PDF yang kita baca dan menambahkan catatan atau tanggapan mengenai referensi yang dibaca.

- Buka artikel/file PDF dengan meng-klik dua kali judul artikel yang ada pada central panel.

- Klik icon Highlight pada menu bar, dan tandai teks/paragraf penting pada artikel yang sedang Anda baca.

Klik icon Note pada menu bar, apabila Anda ingin memberikan catatan khusus, atau tanggapan pada bagian tertentu dari artikel yang sedang dibaca.

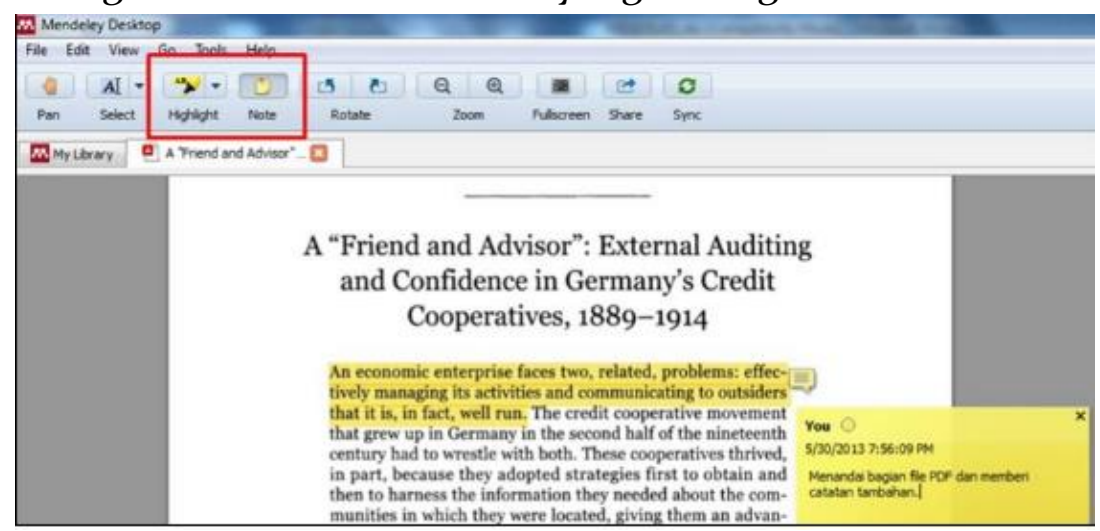

d. Menggabungkan Document

- Klik TOOL pada menu bar, dan pilih Check for duplicates.

- Klik Confirm merger untuk menggabungkan file-file yang sama/ganda.

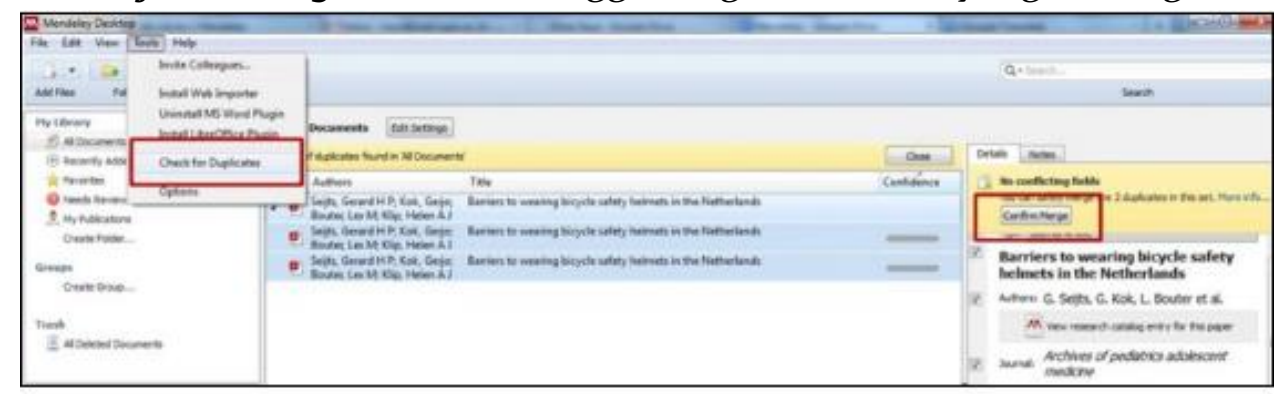




\section{e. Menggabungkan nama penulis, tag atau publikasi ganda}

Dalam pencarian (filter) oleh penulis/tag/publikasi panel, klik nama ganda yang tidak benar, dan drag \& drop ke yang benar untuk mengubah nama tersebut,
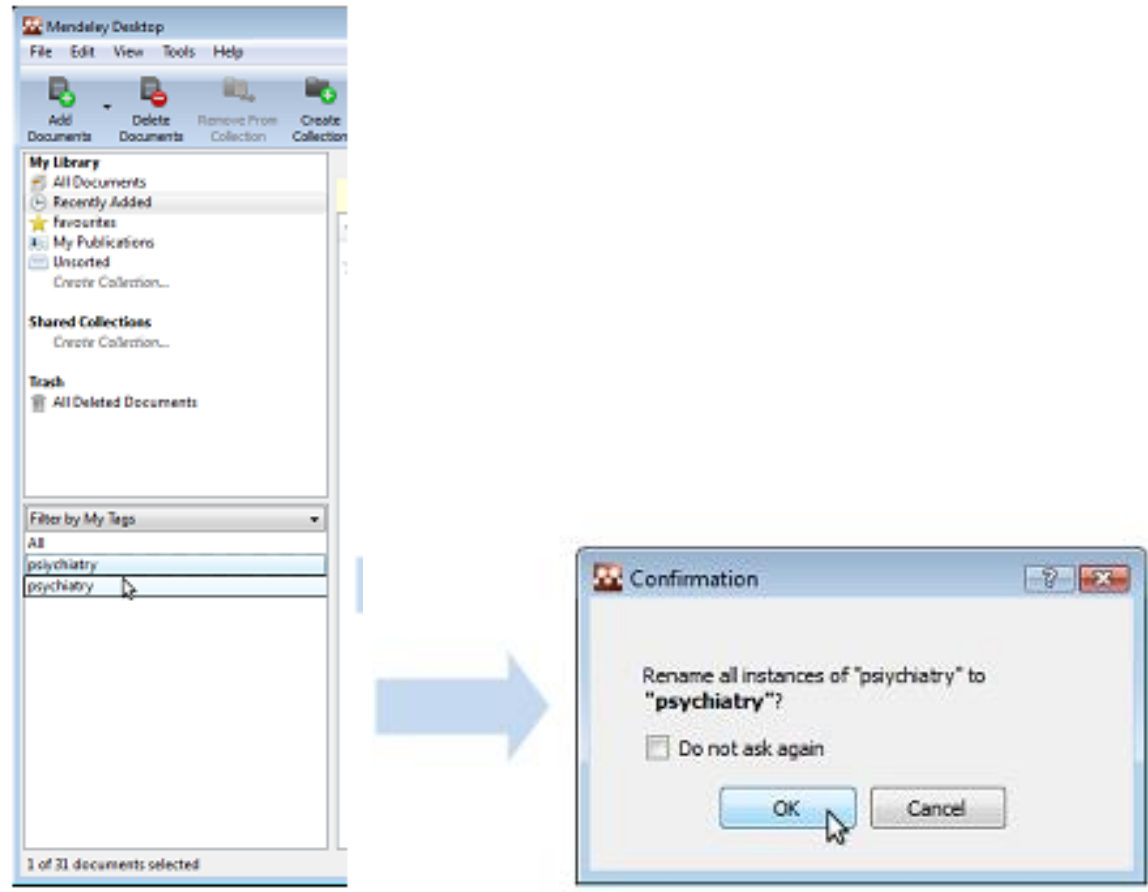

Misalnya jika memiliki dokumen "psychiatry" and "psi ychiatry", rubah yang satu menjadi nama yang benar.

\section{f. Dokumen dapat ditandai dibaca/belum dibaca}

Melacak paper yang belu dibacam ketika dokumen telah ditambahkan ke mendeley, maka dapat ditandai yang belum dibaca menggunakan titik hijau kecil. Jika anda membukanya dalam Mendeley PDF viewer akan ditandai dibaca. Atau cukup klik pada titik hijau untuk beralih dibaca/belum dibaca.

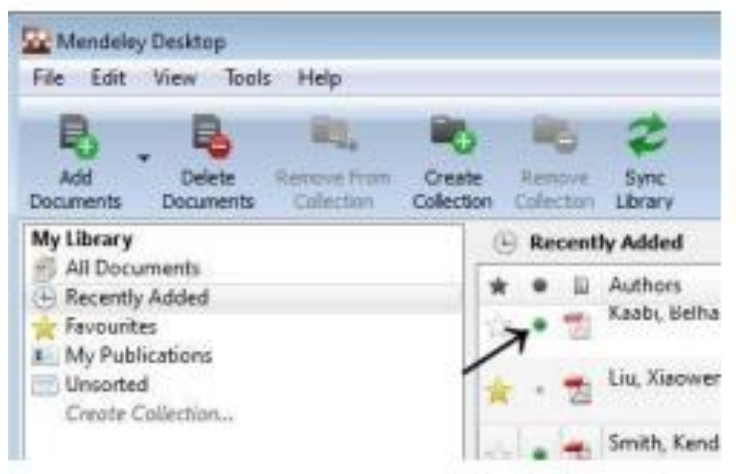

\section{g. Favorit}

Anda dapat menandai dokumen (supaya dokumen dapat dilacak) dengan ikon bintang. Cukup klik bintang, dan klik lagi untuk menghilangkan. Semua dokumen favorit akan muncul dalam koleksi favorit, sehingga and adapt merujuk kemballi kepada mereka dengan satu klik. 


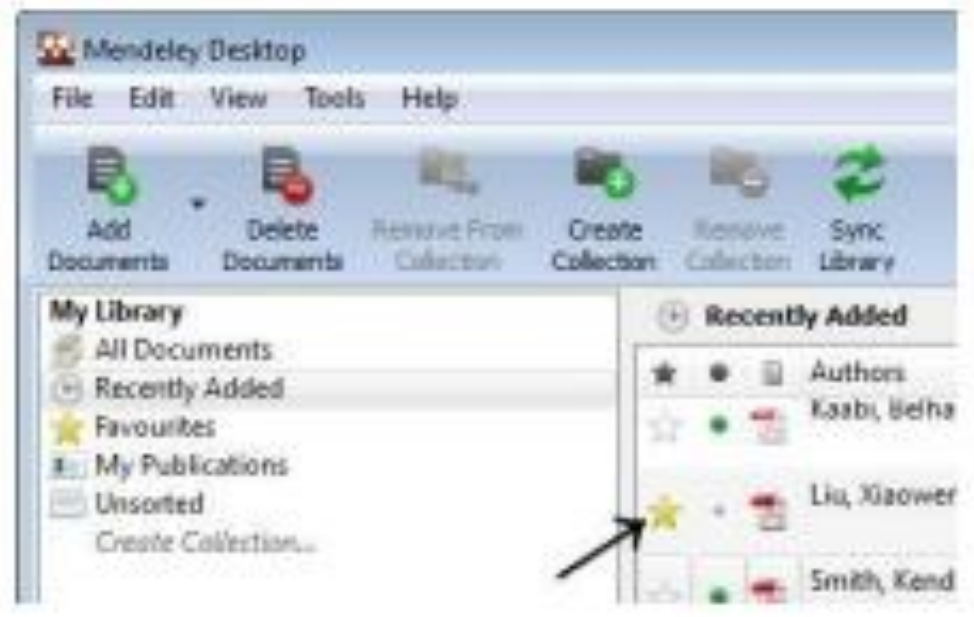

\section{Membuat Daftar Pustaka}

Untuk membuat daftar pustaka secara otomatis, ikuti langkah berikut:

- Posisikan kursor di akhir paper

- Klik Insert Bibliography pada menu bar.

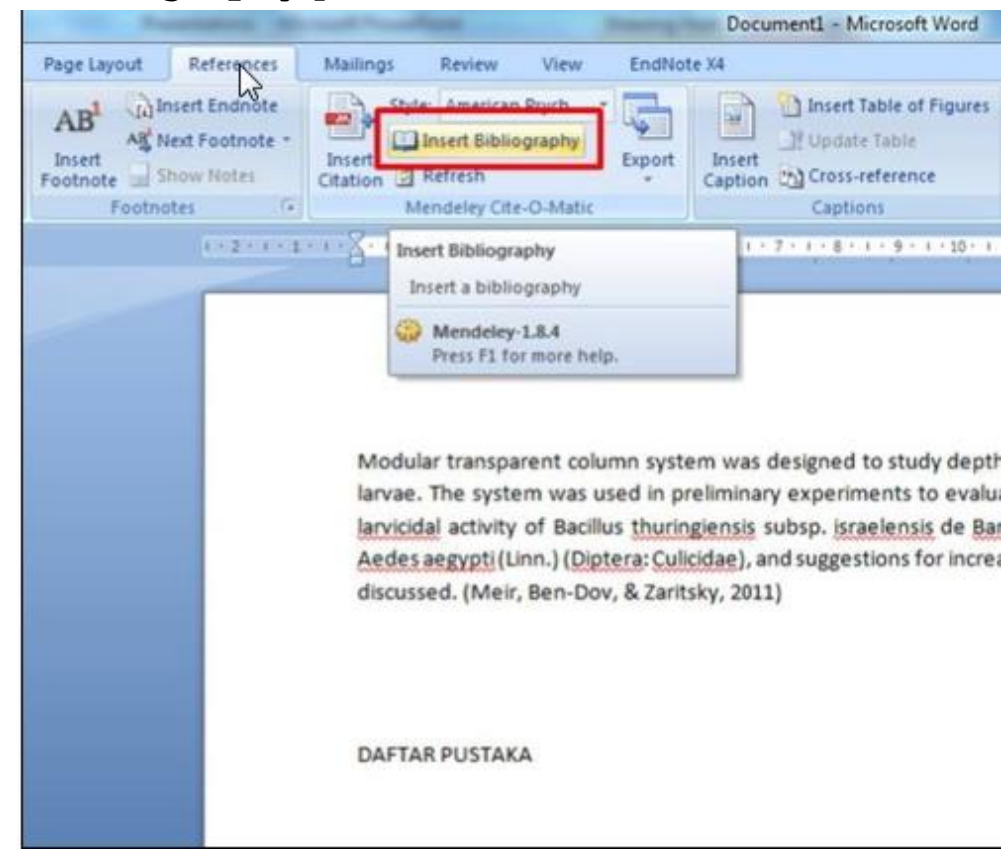

Mendeley secara otomatis akan membuat daftar pustaka dari seluruh referensi yang disitir di dalam dokumen.

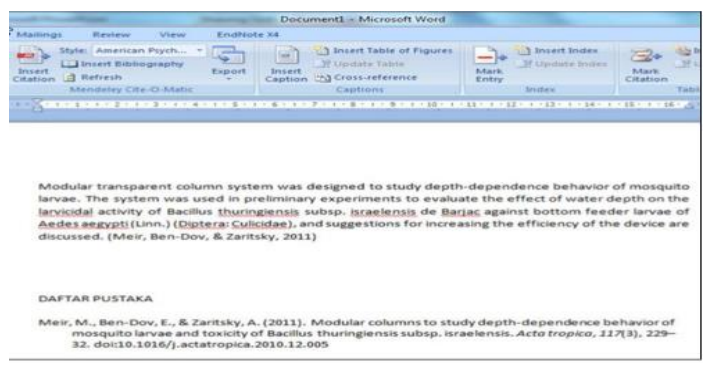




\section{KESIMPULAN}

Pelatihan Manajemen Referensi Publikasi ini merupakan salah satu alternatif untuk guru-guru matematika khususnya yang ada di Kab. Pangkep. Pelatihan ini kami laksanakan di Kab. Pangkep berdasarkan hasil observasi tim PKM, hasil observasi menunjukkan bahwa di Kabupaten Pangkep, khususnya di Kecamatan Pangkajene tingkat publikasi ilmiah para guru masih tergolong rendah karena kurangnya pengetahuan terkait cara mempublikasikan jurnal itu sendiri. Hal inilah yang menjadi acuan Tim PKM untuk melaksanakan kegiatan PKM ini. Hasil dari kegiatan PKM ini guru-guru mampu mengaplikasikan program Mendeley sebagai salah satu aplikasi yang berguna dalam menejemen referensi publikasi.

\section{REFERENSI}

Handoko, I. A. (2016). Mengelola Referensi Publikasi Ilmiah. Padang : Lembaga Pengembangan Teknologi Informasi dan Komunikasi (LPTIK).

Haryanto. (2008). Metode Penulisan Dan Penyajian Karya Ilmiah. Jakarta: Penerbit Buku Kedokteran EGC

Haxa Supriyanto, http://lib.ugm.ac.id/2013/new/?page $\mathrm{id}=583$

Lukman dan Swistien K, 2012, Manajemen Penerbitan Jurnal Ilmiah, Sagung Seto, Jakarta The Mendeley Support Team. 2011. Getting Started with Mendeley. www.mendeley.com 